\title{
Determination of authenticity of Palmyrah toddy using chemical tests
}

\section{T. Glanista*, J. Prabagar, T. Suganja and S. Srivijeindran}

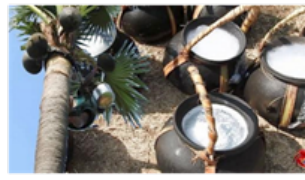

Genuine Palmyrah toddy

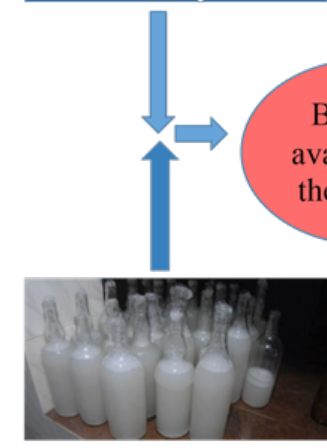

Artificial toddy

Prepared by the fermentation of sugar and starch solution

Both are available in the market \section{(1)} Determination of authenticity of Palmyrah toddy

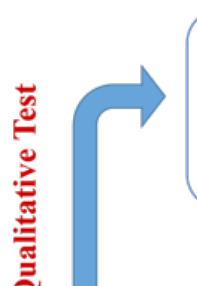

Chloral hydrate test Paraldehyde test Starch test
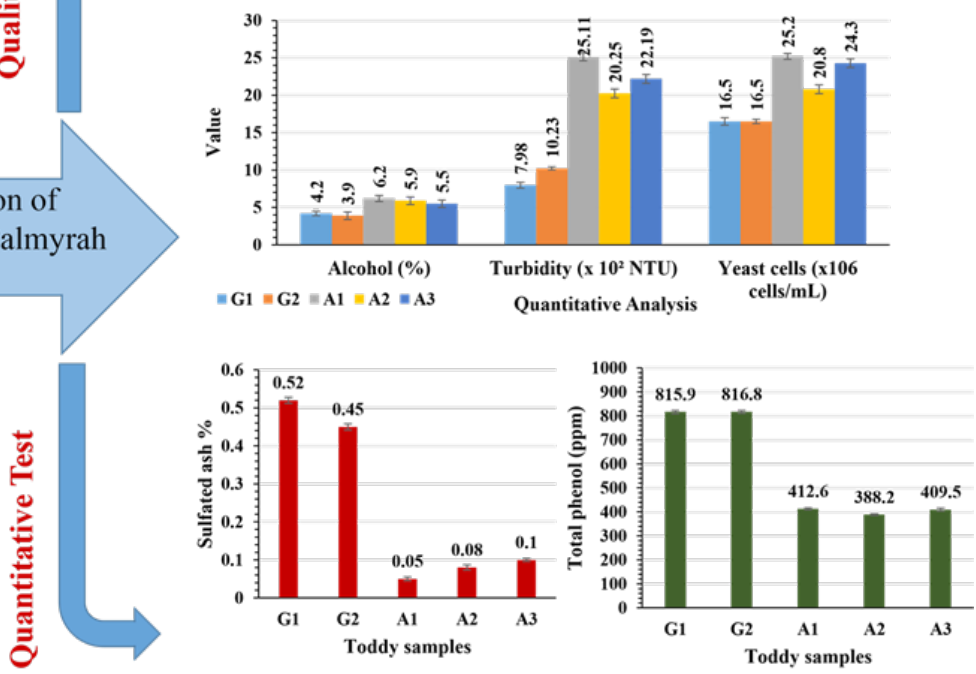

\section{Highlights}

- Present study focuses on identify the authenticity of Palmyrah toddy by chemical tests.

- There are some artificial toddy varieties available in the local market.

- About 50\% lower total phenol content is in artificial toddy than in genuine toddy.

- Sulfated ash content of genuine toddy is higher than that of artificial toddy.

- Qualitative and quantitative tests could be used to identify authentic toddy. 
RESEARCH ARTICLE

\title{
Determination of authenticity of Palmyrah toddy using chemical tests
}

\author{
T. Glanista ${ }^{1, *}$, J. Prabagar $^{2}$, T. Suganja ${ }^{1}$ and S. Srivijeindran ${ }^{1}$ \\ ${ }^{1}$ Palmyrah Research Institute, Kaithady, Jaffna, Sri Lanka. \\ ${ }^{2}$ Department of Chemistry, University of Jaffna, Jaffna, Sri Lanka.
}

Received: 13/08/2020; Accepted: 06/01/2021

\begin{abstract}
Palmyrah toddy is one of the alcoholic drinks prepared by the fermentation of sweet sap of Palmyrah tree (Borassus flabellifer). There are, however, some adulterated toddy samples available in the local market. This study was focused to identify the authenticity of Palmyrah toddy using chemical tests. Chloral hydrate and starch were only present in artificial toddy samples and they had higher alcohol contents $(5.5-6.2 \% \mathrm{v} / \mathrm{v})$, turbidity (2025-2511 NTU) and yeast count $\left(20.8 \times 10^{6}-25.2 \times 10^{6}\right.$ cells $/$ $\mathrm{mL})$ than the genuine toddy samples $(3.9-4.2 \% \mathrm{v} / \mathrm{v}),(798-1023$ NTU) and ( $15.9 \times 10^{6}-16.5 \times 10^{6}$ cells $\left./ \mathrm{mL}\right)$ respectively, while there is no significant difference between genuine and artificial toddy in ${ }^{\circ}$ Brix, acidity and conductivity. Results reveal that the total phenol content of genuine toddy samples were in the range of 815.9-861.8 ppm while artificial toddy samples were 388.2$412.6 \mathrm{ppm}$. Nearly $50 \%$ lower total phenol content in artificial toddy than in genuine toddy. Sulfated ash contents of genuine toddy samples were found to be in the range of 0.45 to $0.52 \mathrm{~g} / 100$ $\mathrm{mL}$ and artificial toddy showed higher range from 0.05 to 0.10 $\mathrm{g} / 100 \mathrm{~mL}$ compared to genuine toddy. This study reveals that total phenol content, sulfated ash and qualitative tests are the most reliable to distinguish artificial toddy samples.
\end{abstract}

Keywords: Genuine toddy; artificial toddy; sulfated ash; total phenol; fermentation.

\section{INTRODUCTION}

Palmyrah (Borassus flabellifer) palm is a valuable economic plant which is mainly distributed in Northern and Eastern provinces of Sri Lanka (Jansz et al., 2002). A Significant number of families are directly or indirectly employed in Palmyrah based industries. Palmyrah toddy is a sweetish, milky white traditional mild alcoholic drink prepared by the fermentation of sap from young inflorescence of tropical male and female plants belonging to Palmae family (Borassus flabellifer) ( Theivendirarajah., 2008). The spadices of male and female Palmyrah plants appear and flowering occur from early January to late July. The male plant flowers in January and matures in two months, while the female plant starts flowering in early March .The inflorescences of matured palms are tapped and the sweet sap is collected into clean opened earthen pots. The Palmyrah sweet sap contains sugars 10-16\% (w/v), vitamins and minerals creating a good culture medium for the growth of microorganisms in the atmosphere. (Theivendirarajah et al., 1987; Ezeagu et al., 2003).Yeast and bacteria (Bacillus cereus, B.sphericus, B.firmus) are the commonly found microbes in the sweet sap that convert sugars into ethyl alcohol and carbon dioxide during the natural fermentation. As time passes, ethanol content of toddy decreases further as it is converted to acetic acid by these microorganisms (Theivendirarajah \& Chrystopher, 1986). Thus, Palmyrah toddy has become a very important resource in the NorthEast part of Sri Lanka among other traditionally found resources like agriculture and fisheries. It generates a high income for families who live on it. Palm development cooperative societies produce Palmyrah bottled toddy which can contribute much to the economic development of Sri Lanka. There have been several complaints made by public with respect to adulterated toddy types which are in the market with low cost as artificial toddy. It can be made easily by the fermentation of sugar and starch solutions (Ramanah et al., 2018). Thus, toddy has to be ensured whether it is pure or artificial and it is a big challenge as sweet sap and added sugar both contain sucrose which undergoes natural fermentation. Therefore, this research has been undertaken to develop a suitable method for the determination of authenticity of Palmyrah toddy to identify the quality of toddy samples which are obtained from Palmyrah trees and also to prevent artificial forms of toddy entering to the market.

\section{MATERIALS AND METHODS}

\section{Location of research}

This research work was carried out in the Analytical Laboratory at Palmyah Research Institute, Jaffna.

\section{Sampling method}

Genuine fresh and bottled Palmyrah toddy samples were received from different Palm Development Co-operative Societies in the Northern Province, Sri Lanka, Suspicious toddy samples were collected from the market, while artificial toddy samples were prepared in the analytical laboratory at Palmyrah Research Institute. Toddy samples were categorized into five different groups:

G1: Fresh toddy samples directly received from palm tappers designated $(\mathrm{n}=30)$

G2: Genuine bottled toddy collected from Palm Development Co-operative Societies designated $(n=30)$ 
A1: Suspicious toddy samples collected from market designated $(\mathrm{n}=30)$

A2: Artificial toddy samples prepared using sugar solutions $\sin$ the Analytical laboratory designated $(\mathrm{n}=10)$

A3: Artificial toddy samples prepared using cooked rice samples in the Analytical laboratory designated $(n=10)$.

\section{Fermentation procedure}

\section{Method of preparation of artificial toddy using sugar solutions}

$50.0 \mathrm{~mL}$ of toddy inoculum, $0.5 \mathrm{~g} \mathrm{NPK}$ as nutrient and $0.5 \mathrm{~g}$ antibacterial agent $\left(\mathrm{Na}_{2} \mathrm{~S}_{2} \mathrm{O}_{5}\right)$ were added to the $16 \%$ $1000.0 \mathrm{~mL}$ sugar solution. Alcohol content was monitored every day until it researched the maximum. On the $9^{\text {th }}$ day, the maximum alcohol content was obtained and on that day chemical tests were carried out.

\section{Method of preparation of artificial toddy using cooked rice}

Commercial yeast $(1.0 \mathrm{~g})$, NPK $(0.5 \mathrm{~g})$ as nutrient, antibacterial agent $\left(\mathrm{Na}_{2} \mathrm{~S}_{2} \mathrm{O}_{5}, 0.5 \mathrm{~g}\right)$ and cooked rice (100.0 g) were added to the $1000.0 \mathrm{~mL}$ of water in a $2.5 \mathrm{~L}$ conical flask and the alcohol content was monitored every day to obtain the maximum value. As on the $7^{\text {th }}$ day, maximum alcohol content was obtained, chemical tests were carried out.

\section{Quantitative analysis of toddy samples}

Total soluble solids (TSS) in the toddy samples were determined directly using Refractometer at ambient temperature and expressed values in Brix as described by Tharmaratnam et al.,(2018). Acidity was determined using the SLS: 729:1985 as described (Xia et al., 2011). Conductivity measurements of toddy samples were carried out with the conductivity meter at ambient temperature as described by Carreon-Alvarez et al., (2016). Alcohol content was determined directly using Ebulliometer Dujardin-Salleron for each toddy sample at ambient temperature $\left(30^{\circ} \mathrm{C}\right)$ as reported (Xia et al., 2011). Turbidity of the samples was measured using the turbidity meter at ambient temperature (Niu et al., 2010). The total phenolic content was determined as described by Xia (2011) using Folin-Ciocalteu reagent. Yeast cells of toddy samples were counted using hemocytometer and cells were observed in high magnification as described by Jayathilake et al., (1999). Sulfated ash content was determined by pipetting out $10.00 \mathrm{~mL}$ of toddy sample into a silica crucible and igniting in an electric furnace until the sample got charred. Then $1.00 \mathrm{~mL}$ of $\mathrm{H}_{2} \mathrm{SO}_{4}$, was added and heated gently until the white fumes were no longer evolved and ignited at 500 ${ }^{\circ} \mathrm{C} \pm 25^{\circ} \mathrm{C}$. The crucible was allowed to cool, few drops of $\mathrm{H}_{2} \mathrm{SO}_{4}$ were added to the sample and heated, and crucible was placed in the muffle furnace. After the ignition, the sample was allowed to cool and then weighed. This was repeated until the sample reached a constant weight as described earlier (Ramanah et al., 2018).

Further, different mixtures of genuine and artificial toddy samples (A2) were prepared and sulfated ash content was measured (Table 1).

\section{Qualitative analysis of the toddy samples}

\section{Chloral hydrate test}

Chloral hydrate was tested as described in the IS 8538:2004. A toddy sample $(2.0 \mathrm{~mL})$ was taken into a test tube. Freshly distilled pyridine $(5.0 \mathrm{~mL})$ and $3.0 \mathrm{~mL}$ of sodium hydroxide were added and mixed the contents thoroughly. The test tube was kept in the boiling water bath for 5 to 6 min. The presence of chloral hydrate was indicated by pyridine layer turning pink.

\section{Paraldehyde test}

Paraldehyde was tested according to the method of IS $8538: 2004$. A toddy sample $(25.0 \mathrm{~mL})$ was taken in a test tube and distilled after adding $25.0 \mathrm{~mL}$ of the sulphuric acid. The distillate $(22.5 \mathrm{~mL})$ was collected in to a collection tube being cooled in ice. The Schiff's reagent $(2.5 \mathrm{~mL})$ was added and after $25 \mathrm{~min}$, the violet colour against the control at $560 \mathrm{~nm}$ was recorded.

Table 1: Mixture $\%$ of genuine and artificial toddy

\begin{tabular}{ccc}
\hline Sample No & Genuine toddy (\%) & Artificial toddy (A2) (\%) \\
\hline 1 & 100 & 0 \\
\hline 2 & 90 & 10 \\
\hline 3 & 80 & 20 \\
\hline 4 & 70 & 30 \\
\hline 5 & 60 & 40 \\
\hline 6 & 50 & 50 \\
\hline 7 & 40 & 60 \\
\hline 8 & 30 & 70 \\
\hline 9 & 20 & 80 \\
\hline 10 & 10 & 90 \\
\hline 11 & 0 & 100 \\
\hline
\end{tabular}


Starch test

A toddy sample $(1.0 \mathrm{~mL})$ was boiled and cooled. Then 1.0 $\mathrm{mL}$ of an aqueous solution containing $0.2 \%$ Iodine and $0.4 \%$ Potassium Iodide $\left(1_{2} / \mathrm{KI}\right.$ reagent $)$ was added. The colour development was compared using an analytical grade starch as the control as described by Cochran et al., (2008).

\section{Statistical analysis}

The data were statistically analyzed using Minitab 13 software at $95 \%$ confidence interval and reported as mean \pm SD. The differences among the experimental groups were identified by one-way analysis of variance (ANOVA) using Duncan's multiple range test. The statistical significance was considered at $\mathrm{P}<0.05$. All experiments were repeated at least three times.

\section{RESULTS AND DISCUSSION}

In order to identify the authenticity of Palmyrah toddy using qualitative and quantitative analysis of alcohol content, acidity, Brix, sulfated ash, turbidity, conductivity, yeast count, chloral hydrate, paraldehyde and starch were analyzed and the results are reported here.

\section{Quantitative analysis}

In the present study, Figure 1 indicates the ${ }^{\circ}$ Brix, acidity and conductivity of toddy samples. ${ }^{\circ}$ Brix value is usually employed to determine sugar content. This parameter varied from 6.18 to 6.52 . Acidity and conductivity were found in the range of $0.54 \%-0.65 \%$ and $2.25 \mu \mathrm{S} / \mathrm{m}-2.58 \mu \mathrm{S} / \mathrm{m}$ respectively. According to the ANOVA test results, $\mathrm{P}$ value is greater than 0.05 for all parameters. As natural toddy is of high cost in the market, toddy makers produce artificial toddy using water, alcohol, starch, sugar and commercial yeast and release to the market with low cost. After dilution of the toddy with water, parameters such as ${ }^{\circ}$ Brix, acidity and conductivity are adjusted by adding adulterants to obtain the desired toddy by toddy makers. That's why the results indicate that the ${ }^{\circ}$ Brix, acidity and conductivity of the different toddy samples were not significantly different from each other.

The quantitative test results of alcohol, turbidity and yeast cells are reported in Figure 2. Artificial toddy samples are having higher alcohol content (5.5 - $6.2 \% \mathrm{v} / \mathrm{v})$, turbidity (2025-2511 NTU) and yeast cells count $(20.8 \mathrm{x}$ $10^{6}-25.2 \times 10^{6}$ cells $\left./ \mathrm{mL}\right)$ than the genuine Palmyrah toddy samples (3.9- $4.2 \% \mathrm{v} / \mathrm{v}),(798-1023 \mathrm{NTU})$ and $(15.9 \mathrm{x}$ $10^{6}-16.5 \times 10^{6}$ cells $\left./ \mathrm{mL}\right)$ respectively. The ANOVA test results showed that the P-values are less than 0.05 for above parameters, indicating that the alcohol, turbidity and yeast cells of the different toddy samples were significantly different from one another. In pair wise comparisons, there was a significant difference between (G1-G2) and (A1-A3), while there was no significant difference inside the groups. This difference can be raised while using commercial yeast and starch to produce the adulterated toddy to reach the higher alcohol strength to create the demand in the toddy market by the toddy makers.

Total phenol content of toddy samples were analyzed using colorimetric analysis using Folin - Ciocalteu reagent . Absorbance was measured at $745 \mathrm{~nm}$. It was expressed as Gallic acid equivalents. Total phenol content of genuine toddy samples were in the range of 815.9-861.8 ppm while artificial toddy samples were 388.2-412.6 ppm. Nearly $50 \%$ lower total phenol content in artificial toddy than in genuine toddy (Figure 3). The ANOVA test showed that the P-value is less than 0.05 , which indicates that different toddy samples were significantly different from each other. In pair wise comparisons, there was a significant difference between (G1-G2) and (A1-A3), while there was no significant difference inside the groups. Similar results were obtained in the research on total phenol content of toddy as a tool of checking adulteration for coconut toddy samples (Udeshini \& Seneviratne; 2014).

Sulfated ash contents of genuine Palmyrah toddy samples were found in the range of 0.45 to $0.52 \mathrm{~g} / 100 \mathrm{~mL}$ and artificial toddy showed the range from 0.05 to 0.10 $\mathrm{g} / 100 \mathrm{~mL}$ (Figure 4). Sulfated ash content of artificial toddy

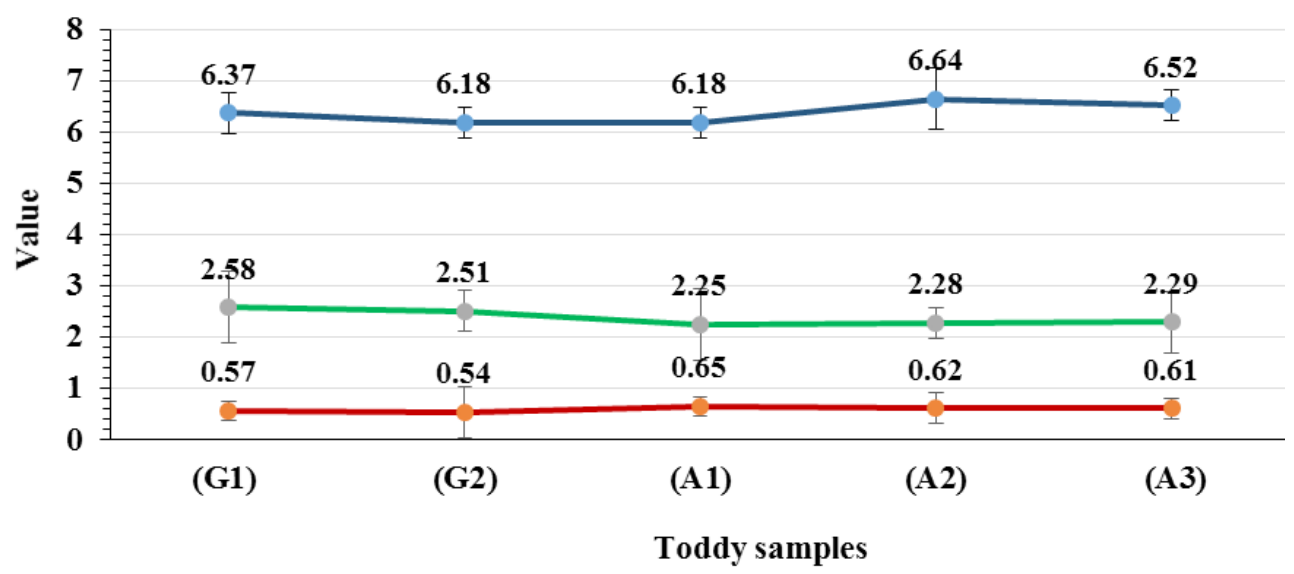

—-Brix Value $\quad-$ Acidity (\%) - - Conductivity $(\mu \mathrm{S} / \mathrm{m})$

Figure 1: ${ }^{\circ}$ Brix, acidity and conductivity in Toddy samples. 


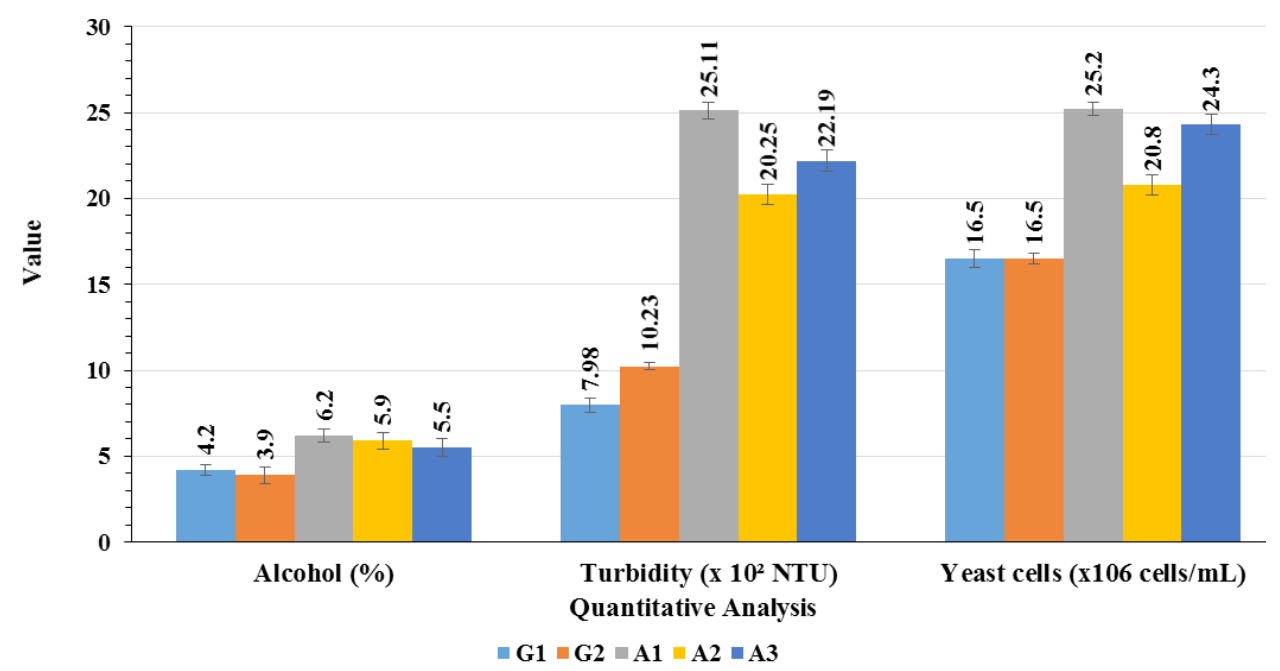

Figure 2: Alcohol content, turbidity and yeast count in toddy samples.

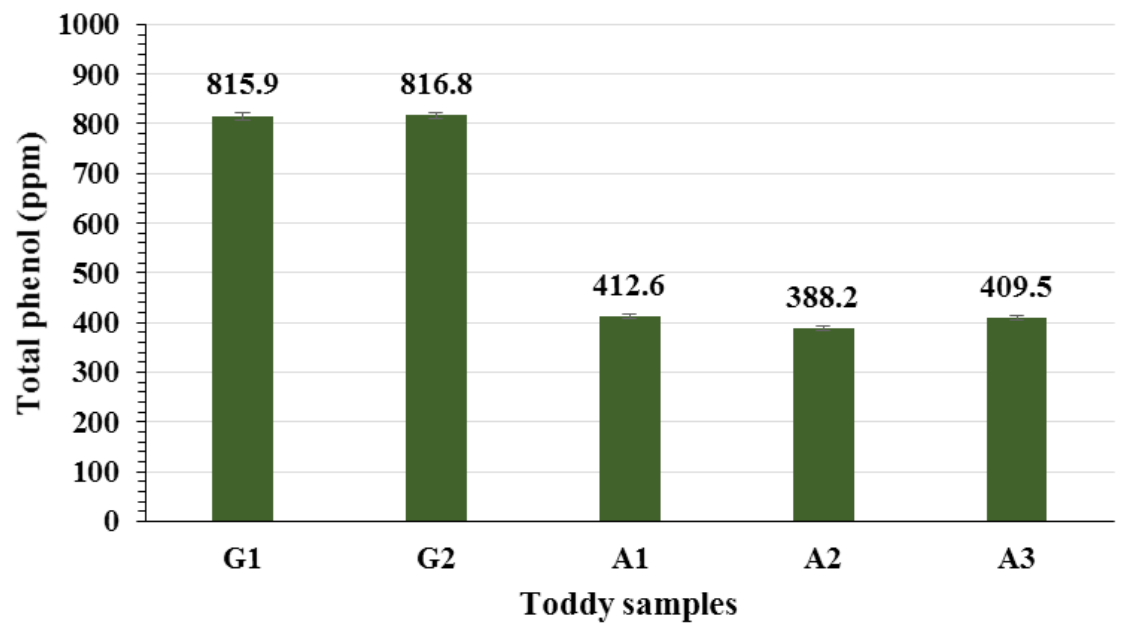

Figure 3: Total phenol content in toddy samples.

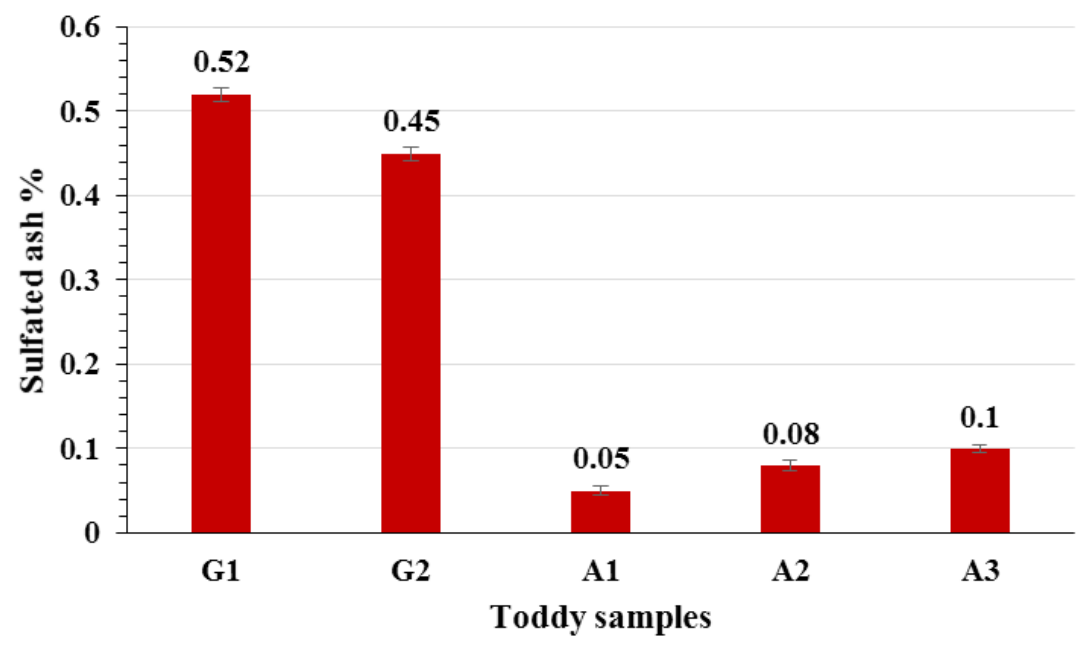

Figure 4: Sulfated ash content in toddy samples. 


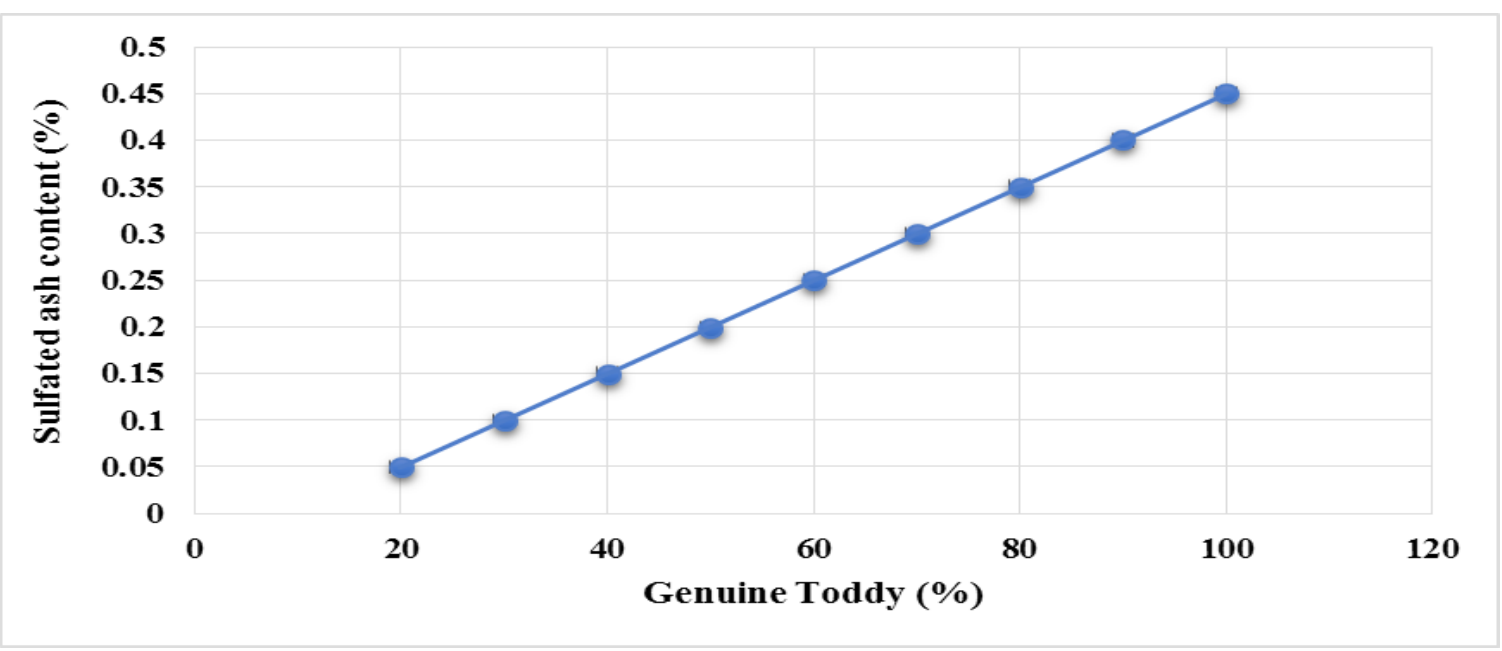

Figure 5: Genuine toddy (\%) in mixtures of genuine and artificial toddy and their sulfated ash contents (\%).

Table 2: Test results for the presence of chloral hydrate in toddy samples

\begin{tabular}{lll}
\hline Toddy samples & Observation & Results \\
\hline G1 & Pink layer was not observed & Absent \\
\hline G2 & Pink layer was not observed & Absent \\
\hline A1 & Pink layer was observed & Present \\
\hline A2 & Pink layer was not observed & Absent \\
\hline A3 & Pink layer was not observed & Absent \\
\hline
\end{tabular}

Table 3: Test results for the presence of starch in toddy samples

\begin{tabular}{lll}
\hline Toddy samples & Observation & Results \\
\hline G1 & No color appeared & Absent \\
\hline G2 & No color appeared & Absent \\
\hline A1 & Blue color appeared & Present \\
\hline A2 & No color appeared & Absent \\
\hline A3 & Blue color appeared & Present \\
\hline
\end{tabular}

Table 4: Test for the presence of paraldehyde in toddy samples

\begin{tabular}{lll}
\hline Toddy samples & Observation & Results \\
\hline G1 & No color appeared & Absent \\
\hline G2 & No color appeared & Absent \\
\hline A1 & No color appeared & Absent \\
\hline A2 & No color appeared & Absent \\
\hline A3 & No color appeared & Absent \\
\hline
\end{tabular}

was significantly low. According to ANOVA test, P-value is less than 0.05 , which indicates that different toddy samples were significantly different from one another. In pair wise comparisons, there was a significant difference between (G1-G2) and (A1-A3) while there was no significant difference inside the groups. Similar results were obtained by in the research on authenticity testing of coconut toddy samples (palm wine) using sulfated ash content (Ramanah, et al., 2018). This shows that the mineral components are in greater abundance in genuine toddy than artificial toddy.

Figure 5, illustrates the relationship between the genuine Palmyrah toddy $\%$ in mixtures of genuine and artificial toddy prepared and sulfated ash contents at ambient temperature. Plotting the values of genuine toddy $\%$ in mixtures against sulfated ash content $\%$ of the mixtures gives linear relations. It indicates clearly the possible influence of mineral components of toddy on its genuine toddy $\%$.

\section{Qualitative analysis}

Chloral hydrate, paraldehyde and starch were analyzed in each toddy sample (Tables 2-4). Palmyrah toddy (G1 and G2) is a natural drink which doesn't contain starch and other chemical substances. Therefore, they showed negative results for chloral hydrate and starch tests. But A1 sample contained chloral hydrate, while A1 and A3 showed positive results for starch. The reason must be the use of starch solutions in the preparation of artificial toddy 
and adulterated with chemical substances, such as chloral hydrate. Using these substances, it is easy to increase the consumer demand of the toddy and to make more profit. Thus, the A1 became positive for starch and chloral hydrate tests. Also A3 might be prepared by diluting the genuine Palmyrah toddy with adulterated with chloral hydrate. Therefore, it showed positive result only for chloral hydrate test and all toddy samples showed negative result for the presence of paraldehyde because Palmyrah genuine toddy never contains paraldehyde substance and artificial toddy producers might not use this substance in the toddy production.

\section{CONCLUSIONS}

Palmyrah toddy is a well-known alcoholic drink since ancient times in Sri Lanka. It is traditionally prepared by the fermentation of sweet sap from young inflorescence of Palmyrah tree (Borassus flabellifer). As it has a high demand in the market, toddy makers are producing adulterated toddy using water, alcohol, starch, sugar and commercial yeast and release in the market with low cost. Hence, the challenge was taken to identify the authenticity of Palmyrah toddy using qualitative and quantitative analysis. The qualitative tests indicate that Chloral hydrate and starch were present in the adulterated toddy collected from market. Further, artificial toddy samples have higher alcohol content, turbidity and yeast counts than the genuine toddy samples, while there is no significant difference between genuine and artificial toddy in ${ }^{\circ}$ Brix, acidity and conductivity. Sulfated ash contents of genuine toddy samples were found to be in the range of 0.45 to $0.52 \mathrm{~g} / 100$ $\mathrm{mL}$ and artificial toddy showed the range from 0.05 to $0.10 \mathrm{~g} / 100 \mathrm{~mL}$. Results indicate that total phenol, sulfated ash and qualitative tests are the most reliable tests while alcohol contents, turbidity and yeast cells are the least reliable tests when distinguish authentic Palmyah toddy from adulterated toddy samples.

\section{ACKNOWLEDGEMENTS}

Authors like to thank the Palmyrah Development Board for the financial support and the Palmyrah Research Institute for providing necessary facilities.

\section{DECLARATION OF CONFLICT OF INTEREST}

The authors declare no competing interests.

\section{REFERENCES}

Carreon-Alvarez, A., Suárez-Gómez, A., Zurita, F., GómezSalazar, S., Soltero, J., Barcena-Soto, M., \& MorenoMedrano, E.D. (2016). Assessment of physicochemical properties of tequila brands: Authentication and quality. Journal of Chemistry, 2016: 1-13. https://doi. org/10.1155/2016/6254942.

Chrystopher, R.K. and Theivendirarajah, K. (1988) Palmyrah palm wine part II: improvements in alcohol production. Journal of the National Science Foundation of Sri Lanka, 16(2): 147-157. DOI: http:// doi.org/10.4038/jnsfsr.v16i2.8247.

Cochran, B., Lunday, D. and Miskevich, F. (2008). Kinetic analysis of amylase using quantitative Benedict's and iodine starch reagents. Journal of chemical education 85(3): 401-403. https://doi.org/10.1021/ed085p401.

Ezeagu, I.E., Fafunso, M.A. and Ejezie, F.E. (2003). Biochemical constituents of palmwine. Ecology of food and nutrition, 42(3): 213-222. DOI: 10.1080/03670240390226222.

Hong, D., Lee, G., Jung, N.C. and Jeon, M. (2013). Fast automated yeast cell counting algorithm using brightfield and fluorescence microscopic images. Biological procedures online, 15(1): 1-8. DOI: 10.1186/14809222-15-13.

IS 8538:2004 Indian standard, Alcoholic Drinks - Toddy. Jayathilake, A.N. and Wijeyaratne, S.C. (1999). Biochemical and microbiological changes of Caryota urens (Kithul palm) phloem sap. Vidyodaya Journal of Science. 8: 91- 108.

Jansz, E.R., Wickremasekara, N. and Sumuduni, K.A.V. (2002). A review of the chemistry and biochemistry of seed shoot flour and fruit pulp of the palmyrah palm (Borassus flabellifer L). Journal of the National Science Foundation of Sri Lanka, 30(1-2): 61-87. DOI: 10.4038/jnsfsr.v30i1-2.2562.

Niu, S., Xu, Z., Fang, Y., Zhang, L., Yang, Y., Liao, X. and $\mathrm{Hu}, \mathrm{X}$. (2010). Comparative study on cloudy apple juice qualities from apple slices treated by high pressure carbon dioxide and mild heat. Innovative Food Science \& Emerging Technologies, 11(1): 91-97. DOI: 10.1016/j.ifset.2009.09.002.

Ramanah, G., Wimalasena, S., Senadipathi, V., Seniviratne, E. and Suntharalingam, K. (2018). Authenticity Testing of Coconut Toddy Samples (Palm Wine) Using Sulfated Ash Content. Food Science and Technology, 6(1): 2027. DOI: 10.13189/fst.2018.060103.

SLS 729:1985, Sri Lanka Standards Institution, Colombo 3, Sri Lanka, 1985.

Tharmaratnam, G., Navaratnam, P. and SriVijeindran, S. (2018). Preservation of Palmyrah Haustorium, Young Fruit Kernel and Boiled Tuber with Lengthen ShelfLife Consisting their Native Characters. Annals of Biological Research, 9(2): 1-10.

Theivendirarajah, K. (2008). Palmyrah Palm, A Monograph, K. Theivendirarajah, Roxanne Crescent, scarborough, Ontario, Canada, 1: 1-27.

Theivendirarajah, K. and Chrystopher, R.K. (1986). Chemical analysis of palmyrah palm Borassus flabellifer L. wine (toddy). Journal of Science.1: 1-7.

Theivendirarajah, K. and Chrystopher, R.K. (1987). Microflora and microbial activity in palmyrah (Borassus flabellifer) palm wine in Sri Lanka. MIRCEN journal of applied microbiology and biotechnology, 3(1): 23-31. DOI: https://doi.org/10.1007/BF01090492.

Udeshini, D.R.I. and Seneviratne, K.N. (2014). Total phenol content of toddy as a tool of checking adulteration. Proceedings of Annual Research Symposium, Faculty of Graduate Studies. University of Kelaniya.Pp.95.

Xia, Q., Li, R., Zhao, S., Chen, W., Chen, H., Xin, B. and Tang, M. (2011). Chemical composition changes of post-harvest coconut inflorescence sap during natural fermentation. African Journal of Biotechnology, 10(66): 14999-15005. DOI: 10.5897/AJB10.2602. 